\title{
Rethinking Tiebout: The Contribution of Political Fragmentation and Racial/Economic Segregation to the Flint Water Crisis
}

\author{
Richard Casey Sadler and Andrew R. Highsmith
}

\begin{abstract}
The water crisis that has embroiled Flint, Michigan, since 2014 is often explained via the proximate causes of government oversight and punitive emergency management. While these were critical elements in the decision to switch the city's water source, many other forces helped precipitate the crisis. One such force has been an enduring support for Charles Tiebout's model of interlocal competition, through which a region is presumed stronger when fragmented, independent municipalities compete for residents and investment. However, the Tiebout model fails to account for spillover effects, particularly regarding questions of social and regional equity. In this sense, the fragmentation of the Flint metropolitan region-supported through a variety of housing and land use policies over many decades - created the conditions through which suburbs were absolved of responsibility for Flint's decades-long economic crisis. Because of the Tiebout model's inability to address imbalances in population shifts arising from disparities in municipal services, Flint's more affluent suburbs continued to prosper, while Flint grew poorer and experienced infrastructure decline. Underlying this pattern of inequality has been a long history of racial segregation and massive deindustrialization, which concentrated the region's black population in the economically depressed central city. The Flint Water Crisis is thus a classic example of an environmental injustice, as policies were set in motion, which led to the creation of a politically separate and majority-black municipality with concentrated poverty, while nearby municipalities - most of them overwhelmingly white-accepted little responsibility for the legacy costs created by the region's starkly uneven patterns of metropolitan development.
\end{abstract}

Keywords: urban planning; social justice; public health; lead poisoning; land use; Tiebout Model

\section{INTRODUCTION}

$\mathbf{S}$ INCE THE SPRING OF 2014, residents of the hard luck city of Flint, Michigan, have experienced a toxic lead-in-water catastrophe rooted simultaneously in contemporary government malfeasance and the city's long and complex history of inequality. The crisis formally began in April 2014, when a state-appointed emergency manager and staff-in a bid to cut costs in this financially strapped city - opted to use the highly corrosive Flint

Dr. Sadler is an assistant professor in the Division of Public Health, Michigan State University, Flint, Michigan. Dr. Highsmith is an assistant professor in the Department of History, University of California, Irvine, Irvine, California.
River as the city's water source without implementing proper corrosion control, causing lead and other dangerous contaminants from the city's aging water pipes to leach into the water supply. ${ }^{1}$ Investigations conducted in the wake of the citywide lead exposure leave little room

${ }^{1}$ Mark Brush, et al. "TIMELINE: Here's How the Flint Water Crisis Unfolded." Michigan Radio, 21 December 2015. <http:// michiganradio.org/post/timeline-heres-how-flint-water-crisisunfolded\#stream $/ 0>$. (Last accessed on July 18, 2016); Mona Hanna-Attisha, et al. "Elevated Blood Lead Levels in Children Associated with the Flint Drinking Water Crisis: A Spatial Analysis of Risk and Public Health Response." American Journal of Public Health 106 (2016): 283-290; Jeremy C.F. Lin, Jean Rutter, and Haeyoun Park. "Events That Led to Flint's Water Crisis." The New York Times, 21 January 2016. 
for doubt that the Flint Water Crisis (FWC) is, in large measure, a product of severe government mismanagement. $^{2}$

In reality, though, the tangled roots of the FWC also stretch back deep into the twentieth century, long before the city's emergency managers elected to change the public water source. Over the past three-quarters of a century, a harsh mix of disinvestment, "white flight," metropolitan political fragmentation, and persistent racial discrimination transformed this once economically vibrant although deeply divided city into one of the poorest, most racially segregated metropolitan regions in the United States. In the end, these forces decimated the local tax base and eroded the city's infrastructure, thus setting the stage for the state's 2011 takeover of the municipal government and the ensuing $\mathrm{FWC}^{3}$

An examination of the long history leading up to the FWC points to the harmful legacies of Charles $M$. Tiebout's influential model of metropolitan fragmentation and interlocal competition. During the middle decades of the twentieth century, as Flint was gaining stature as a manufacturing hub of the General Motors Corporation (GM), tens of thousands of white city dwellers "voted with their feet," as Tiebout expected and hoped they would, and departed Flint for new frontiers in suburbia. Once ensconced in their new communities, white suburbanites created new independent governments, resisted affiliations with Flint and its people-particularly African Americans and the poor-and insulated themselves from the urban economic crisis that ultimately precipitated the FWC. Although Tiebout's model was (and remains) popular among many policymakers and ordinary suburbanites, its implementation has consistently hardened social inequalities and thwarted efforts to provide basic public services in cities such as Flint. $^{4}$

The FWC is, in many ways, a culminating event in the city's decades-long urban crisis. Although this public health disaster has largely unfolded within the city of Flint, the origins of the calamity are thoroughly metropolitan in nature. Our intention here is to provide a historical case study of the social and land use policies that led to the FWC, one that demonstrates the pernicious effects of metropolitan fragmentation and sprawl driven by political parochialism, persistent racial antagonism, and a lack of economic diversification.

${ }^{2}$ Flint Water Advisory Task Force. "Final Report." March 21, 2016. <https://www.michigan.gov/documents/snyder/FWATF FINAL_REPORT_21March2016_517805_7.pdf>. (Last accessed on July 18, 2016).

${ }^{3}$ Andrew R. Highsmith. Demolition Means Progress: Flint, Michigan, and the Fate of the American Metropolis (University of Chicago Press, 2015); Andrew R. Highsmith. "Failing Flint." Los Angeles Times, 27 January 2016.

${ }^{4}$ Michael Howell Moroney. "The Tiebout Hypothesis 50 Years Later: Lessons and Lingering Challenges for Metropolitan Governance in the 21st century." Public Administration Review 68 (2008): 97-109; Charles M. Tiebout. "A Pure Theory of Local Expenditures." The Journal of Political Economy 64 (1956): 416-424.

\section{The Tiebout model within the Flint context}

The Tiebout model asserts that metropolitan regions are best constituted by a range of competing municipalities offering different taxing systems and service packages. Within this market-based framework, individual residents or businesses are left to choose and invest in the communities that best suit their needs. ${ }^{5}$ The logic behind Tiebout's model is that small units of government encourage competitive efficiency and reduce individual losses associated with the distribution of goods and services over large areas. ${ }^{6}$

The functional effect of this model of governance is a metropolitan region fragmented into many competing units of government. Were geographically separate governance and exacerbated sprawl the only outcomes, ${ }^{7}$ social justice advocates may have fewer objections to the Tiebout model. However, the idea that vote-with-your-feet politics preserves free choice for everyone is inaccurate because few municipalities compete for the socially or economically marginalized, ${ }^{8}$ who are simultaneously often the least mobile, and thus find themselves disproportionately concentrated in high-need, low-tax base municipalities in the older urban core or impoverished inner-ring suburbs. ${ }^{9}$

In fact, scholars have repeatedly shown that the fragmentation of metropolitan areas perpetuates segregation and racial and economic inequality at both municipal ${ }^{10}$ and school district levels. ${ }^{11}$ Furthermore, members of

${ }^{5}$ Pillsung Byun and Adrian X. Esparza. "A Revisionist Model of Suburbanization and Sprawl: The Role of Political Fragmentation, Growth Control, and Spillovers." Journal of Planning Education and Research 24 (2005): 252-264; John I. Carruthers. "Growth at the Fringe: The Influence of Political Fragmentation in United States Metropolitan Areas." Papers in Regional Science 82 (2003): 475-499; Tiebout. "A Pure Theory." 416-424.

${ }^{6}$ Howell-Moroney. "The Tiebout Hypothesis."

${ }^{7}$ Byun and Esparza. "A Revisionist Model."

${ }^{8}$ Dennis C. Mueller. "Achieving the Just Polity." The American Economic Review 64 (1974): 147-152.

${ }^{9}$ Myron Orfield. American Metropolitics: The New Suburban Reality (Brookings Institution Press, 2002).

${ }^{10}$ Ruth Hoogland DeHoog, David Lowery, and William E. Lyons. "Metropolitan Fragmentation and Suburban Ghettos: Some Empirical Observations on Institutional Racism." Journal of Urban Affairs 13 (1991): 479-493; David M.P. Freund. Colored Property: State Policy and White Racial Politics in Suburban America (University of Chicago Press, 2007); Richard Child Hill. "Separate and Unequal: Governmental Inequality in the Metropolis." American Political Science Review 68 (1974): $1557-1568$.

${ }^{11}$ For a sampling of this scholarship, see Jennifer B. Ayscue and Gary Orfield. "School District Lines Stratify Educational Opportunity by Race and Poverty." Race and Social Problems 7 (2015): 5-20; Kendra Bischoff. "School District Fragmentation and Racial Residential Segregation: How Do Boundaries Matter?" Urban Affairs Review 44 (2008): 182-217; Erica Frankenberg. "Splintering School Districts: Understanding the Link between Segregation and Fragmentation." Law \& Social Inquiry 34 (2009): 869-909; Jennifer Jellison Holme and Kara S. Finnigan. "School Diversity, School District Fragmentation, and Metropolitan Policy." Teachers College Record 115 (2013): 129; Gary Orfield. Must We Bus? Segregated Schools and National Policy (Brookings Institution Press, 1978). 
minority communities in fragmented metropolitan areas tend to exhibit poorer economic and health outcomes than their white peers. ${ }^{12}$ Such inequality is not purely a function of economic distress, though, as white racism and public policy support for suburbanization have independent effects on both individual city dwellers and broad patterns of "urban decline." 13 Moreover, sprawl itself has been pegged as a critical but sometimes overlooked issue for civil rights and social justice advocates to consider when addressing issues of concentrated poverty and disadvantage. ${ }^{14}$

Thus, with its myopic view of efficiency and individual responsibility, the Tiebout model fails to account for a variety of socially inequitable spillover effects. ${ }^{15}$ Tiebout's framework also elides the central role of government in producing (and reproducing) inequality. As other scholars have shown, the process of racial and class sorting afforded by federal housing policies promoting suburbanization helped to fragment metropolitan areas, leading to more concentrated poverty in inner-city communities of color and more sprawl in outlying, majority-white areas. ${ }^{16}$ Moreover, residents isolated in low-need/low-tax municipalities do not pay the true cost of regional service provision, thus creating a price distortion. ${ }^{17}$ What were once underdeveloped semirural areas have, in many cases, been built up into affluent, overwhelmingly white suburbs with an artificial sense of prosperity. In assessing the roots of these metropolitan divides, the contributions of federal housing policy cannot be overstated. Indeed, from the creation of the Federal Housing Administration (FHA) in 1934 to the era of fair housing reform in the late 1960s and early 1970s, millions of Americans-all but a tiny fraction of them white-benefitted from government-backed loans for new suburban housing. ${ }^{18}$

\footnotetext{
${ }^{12}$ Casey J. Dawkins. "Tiebout Choice and Residential Segregation by Race in US Metropolitan Areas, 1980-2000." Regional Science and Urban Economics 35 (2005): 734-755; André Malo Hutson, et al. "Metropolitan Fragmentation and Health Disparities: Is There a Link?" Milbank Quarterly 90 (2012): 187-207.

${ }^{13}$ Colin Gordon. Mapping Decline: St. Louis and the Fate of the American City (University of Pennsylvania Press, 2008); Andrew R. Highsmith. "Decline and Renewal in North American Cities." Journal of Urban History 37 (2011): 619-626.

${ }^{14}$ John Powell. "Race, Poverty, and Urban Sprawl: Access to Opportunities through Regional Strategies." Forum for Social Economics 28 (1999): 1-20.

${ }^{15}$ Byun and Esparza. "A Revisionist Model"; HowellMoroney. "The Tiebout Hypothesis."

${ }^{16}$ Freund. Colored Property; Kenneth T. Jackson. Crabgrass Frontier: The Suburbanization of the United States (Oxford University Press, 1985); Thomas J. Sugrue. The Origins of the Urban Crisis: Race and Inequality in Postwar Detroit (Princeton University Press, 1996).

${ }^{17}$ Howell-Moroney. "The Tiebout Hypothesis.'

${ }^{18}$ Lorrie A. Frasure. "Beyond the Myth of the White Middle-Class: Immigrant and Ethnic Minority Settlement in Suburban America." In: Georgia A. Persons, ed., The Expanding Boundaries of Black Politics (Transaction Publishers, 2011); Freund, Colored Property; Jackson, Crabgrass Frontier.
}

Because of these policies, regions with high levels of metropolitan fragmentation have a built-in environmental injustice due to racial segregation, unequal tax bases, and uneven service provision. In addition, as other scholars have concluded, municipal fragmentation unnecessarily complicates the provision and administration of physical infrastructure such as water and sewer systems. ${ }^{19}$

As we demonstrate in the paragraphs to follow, metropolitan Flint-a region exhibiting high levels of socioeconomic segregation and metropolitan fragmentation-is a classic example of the equity problems inherent in the Tiebout model. Throughout this article, we show how the state-sponsored employment of metropolitan fragmentation, spurred by notions of personal responsibility and racially motivated fears of integration, contributed to the environmental injustice now present in Flint. In Figure 1, we present an original framework, entitled "The Causal Chain of the Flint Water Crisis," for navigating through five transitional periods in Flint's history. Our analysis of these five periods, which match the five subsections of the article to follow, illustrates how major events in the city's history combined to pave the way for the FWC. The framework itself grew out of historical research conducted by the authors and inspired by numerous other scholars cited below. The transitional periods within the framework correspond to major changes in development patterns, social and land use policies, and investment practices that directly influenced Flint's trajectory. These include the following: Industrial Growth (and the accompanying sprawl, racial segregation, and rapid urban development), Post-World War II Development (and the ensuing mass suburbanization that reshaped metropolitan areas), New Flint and Regionalism (and the emboldening of suburbs against the center city), Civil Rights and Deindustrialization (and the reshaping of the local economy), and Contemporary Disinvestment (and the fiscal crisis it created).

\section{HISTORICAL STAGES LEADING TO THE FWC}

\section{Industrial growth: sprawl, segregation, and rapid urban development}

Flint's recent history of environmental injustice dates to the growth of the automobile industry before World War II. As the population soared through the 1910s and 1920s due to a massive influx of job-seeking migrants from the American South, the Flint community expanded its use of explicitly racist housing practices to keep the African American population separate from white neighborhoods. ${ }^{20}$ Within the city, rigid forms of racial segregation (many of them rooted in public policies) relegated thousands of black families to overcrowded, polluted, and dilapidated neighborhoods near GM

\footnotetext{
${ }^{19}$ Howard Frumkin, Lawrence Frank, and Richard J. Jackson. Urban Sprawl and Public Health: Designing, Planning, and Building for Healthy Communities (Island Press, 2004); Hutson, et al. "Metropolitan Fragmentation."

${ }^{20}$ Peirce F. Lewis. "Impact of Negro Migration on the Electoral Geography of Flint, Michigan, 1932-1962: A Cartographic Analysis." Annals of the Association of American Geographers 55 (1965): 1-25.
} 


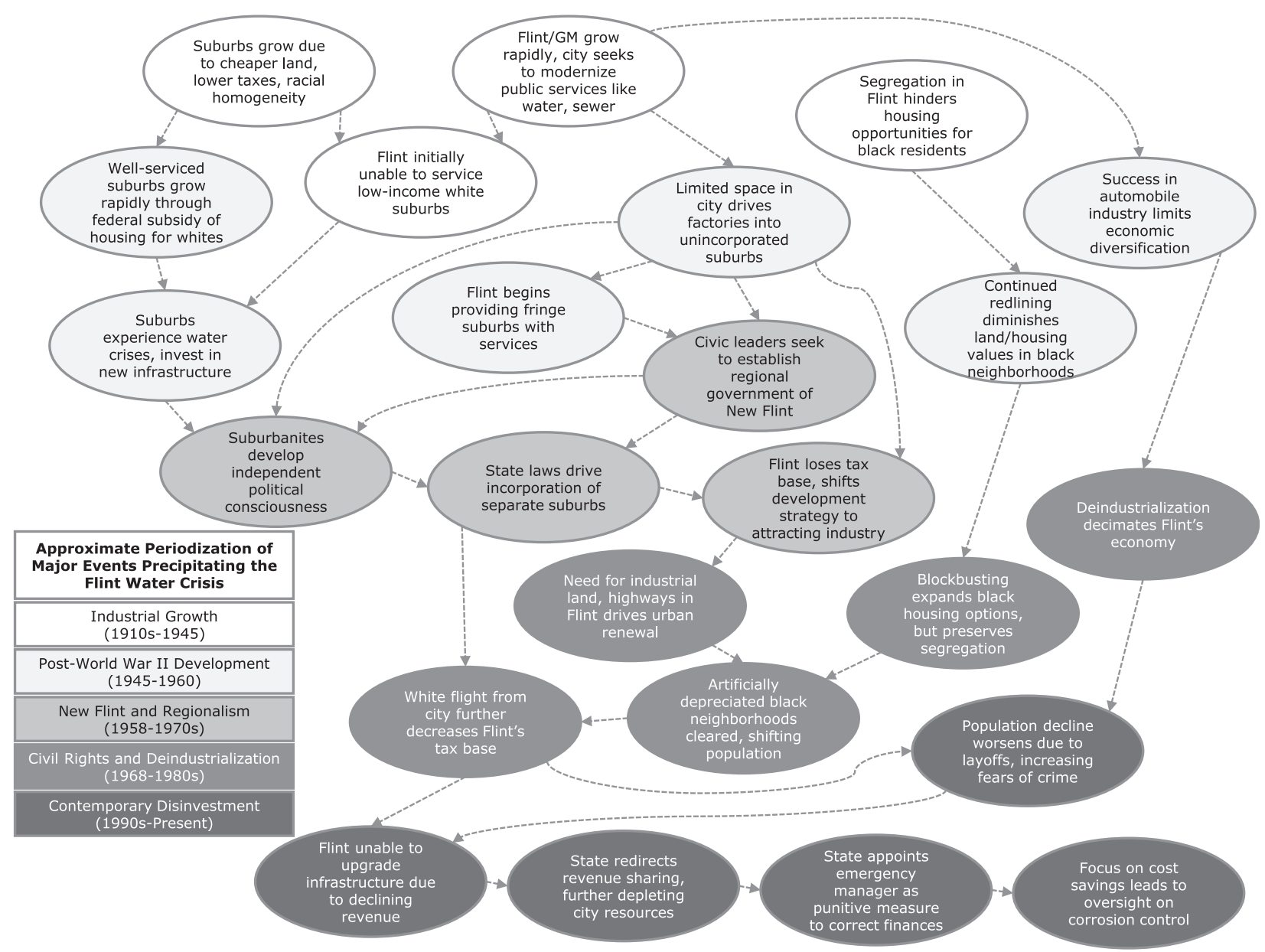

FIG. 1. The causal chain of the Flint Water Crisis.

factories, particularly in the city's North End. Many poor whites settled outside of the city in politically weak suburban townships, where land was cheap, neighborhoods were virtually all white, and modern amenities such as sewers, running water, and electricity were often absent. In fact, the lack of infrastructure outside the Flint city limits meant that most suburbs were initially redlined by local banks and federal housing officials alongside majority-black neighborhoods in the city. ${ }^{21}$

Rapid growth within the city rested to a considerable degree on racial segregation and the separation of ostensibly incompatible land uses. Thus, many middleclass white neighborhoods-where favorable mortgages could be procured-grew up apart from both underdeveloped working-class white suburbs and majority-black urban neighborhoods. GM was also responsible for maintaining segregation. Between 1919 and 1933, the company constructed 3000 new white-only housing units on Flint's west side. ${ }^{22}$

\footnotetext{
${ }^{21}$ Highsmith. Demolition Means Progress, 37-53.

${ }^{22}$ Ibid., 31-32.
}

Throughout this pre-World War II era, the city continued to grow and modernize its services, while suburban areas suffered from poor infrastructure and political underdevelopment. In a lending system, in which mortgages tended to follow sewer lines, ${ }^{23}$ most new housing starts occurred within segregated neighborhoods inside Flint. Further aggravating these metropolitan imbalances, the massive speculative subdivision of tens of thousands of suburban lots meant that Flint could not service all outlying areas with their existing system. ${ }^{24}$ In 1948, public health researchers found that the area's uneven patterns of development were leading to huge public health disparities between white urban neighborhoods and suburban or black urban neighborhoods. ${ }^{25}$

\footnotetext{
${ }^{23}$ Ibid., 45-53, 103-120.

${ }^{24}$ Andrew R. Highsmith. "Demolition Means Progress: Flint, Michigan, and the Deconstruction of the American Dream,' (PhD diss., University of Michigan, 2009), 230-231.

${ }^{25}$ Leonard M. Board and Herbert J. Dunsmore. "Environmental Health Problems Related to Urban Decentralization-As Observed in a Typical Metropolitan Community." American Journal of Public Health 38 (1948): 986-996.
} 


\section{Post-World War II development: mass \\ suburbanization, fragmentation, and crisis}

In the years following World War II, underserviced, sprawling, unincorporated suburban municipalities faced intense pressure to modernize their services to match Flint's well-developed infrastructure, especially as local citizens demanded improved living conditions and federal housing officials became more amenable to subsidizing growth in well-serviced suburbs. As the city's economy boomed, many more white families (some with an explicit antiurban bias) moved to the suburbs, often with the false expectation of urban amenities such as water and sewer lines. During the 1940s and 1950s, these suburban migrations precipitated several major health and infrastructure crises. In 1947, suburban Carman Creek overflowed with untreated sewage, creating a public health emergency. ${ }^{26}$ Concerns also arose over impending suburban water shortages and were ultimately realized when the suburb of Flushing ran out of water in $1954 .{ }^{27}$ By 1956, suburban governments had invested millions of dollars in new water infrastructure (serving one-third of the county's population) and suburban municipalities continued their push to modernize to attract new FHA-backed mortgages.

As the city became more densely packed and corporate investment and manufacturing processes evolved, GM began eyeing the suburbs around Flint for new industrial development. ${ }^{28}$ The siting of factories in suburbs generated a great deal of territoriality in suburban Flint, as site location practices implicitly chose winners and losers in the metropolitan economic landscape. Furthermore, although GM was of paramount importance to the local economy, its success made Flint the least economically diversified region in the nation-a fact that would ultimately have momentous consequences for the city's future. ${ }^{29}$ Viewing Flint's leaders as opportunistically seeking to annex new factories, growing suburban mu-

\footnotetext{
${ }^{26}$ Highsmith. Demolition Means Progress, 107-108.

${ }^{27}$ A collection of quotations from Highsmith's dissertation illustrate water-related crises experienced in the underdeveloped suburbs of metropolitan Flint during the middle decades of the 20 th century. Notably, there is a great deal of similarity between the complaints of mid-century suburbanites and the contemporary exclamations of exasperated community members in Flint. There is also a similarity between the logistical struggles faced by local elected officials in both periods. The quotes regarding mid-century water crises include: "Homeowners not so silently fumed about foul tasting...water"; "The poor water quality...shocked public health officials...[and] sickened untold numbers"; "[Council members] implemented Operation Tanker, a plan to purchase and transport water...[and] workers labored around the clock to deliver... water to thirsty customers"; "Whole communities are concerned about an adequate water supply"; and "These emergencies forced...governing bodies to develop expensive new urban infrastructure projects." See Highsmith. "Demolition Means Progress" 280-285. It is instructive to note that, after World War II, such attitudes fostered an anti-urban bias against the city, as suburbs scrambled to develop their own independent infrastructures.

${ }^{28}$ Highsmith. Demolition Means Progress, 121-134.

${ }^{29}$ Allan Rodgers. "Some Aspects of Industrial Diversification in the United States." Economic Geography 33 (1957): 16-30.
}

nicipalities and school districts sought to retain the tax base for themselves and thus strengthened their antiurban resolve. $^{30}$

Recognizing the need to retain GM's regional investment, Flint's municipal leaders began providing water and other services to several suburban areas, especially for industrial land uses. While the expectation was to incorporate these areas into the central city, the immediate effect was to subsidize further suburban migration. Massive growth in demand by the late 1950s forced the city to reconsider this policy, with the idea of a regional government eventually proposed as a solution to the service problem. ${ }^{31}$

In the end, industrial sprawl further disadvantaged Flint's black residents, most of whom remained locked in the center city, increasingly distant from jobs, and overlooked in the development of new infrastructure. While the suburbs no longer experienced redlining, continued disinvestment from core urban areas and explicitly racial redlining further diminished land values and living conditions in majority-black neighborhoods in the city. ${ }^{32}$

\section{New Flint and regionalism: suburbs versus the city}

During the late 1950s, Flint's civic leaders, including representatives of GM, proposed a solution to the area's uneven metropolitan development by recommending a regional government called New Flint, primarily to coordinate service provision and growth. Yet, because of the tremendous tax burdens that the suburbs had recently incurred through the construction of new infrastructure, many suburbanites developed a "fiercely independent political consciousness." ${ }^{, 33}$ Ushering in an era within Michigan marked by the rejection of regional governance and the triumph of the Tiebout philosophy, ${ }^{34}$ suburban voters strongly opposed this proposaland the Michigan Supreme Court ruled in their favor in $1958^{35}$ - steering a course toward deindustrialization and sociopolitical fragmentation that ultimately led to Flint's 2011 financial emergency and the subsequent water crisis.

These fights to develop infrastructure and retain local government control emboldened suburban residents to adopt new, more parochial identities throughout the 1960s and 1970s. Thus, although it was already well known among social scientists that political fragmentation was inefficient, depressed regional housing markets, and diminished public health, suburban leaders flouted such ideas and sought to retain autonomy above all else to protect segregation and the system of resource and

\footnotetext{
${ }^{30}$ Charles Tilly. Durable Inequality (University of California Press, 1999); Highsmith. Demolition Means Progress, 103-144.

${ }^{31}$ Highsmith. Demolition Means Progress, 121-144.

${ }^{32}$ Ibid., 45-53, 147-199.

${ }^{33}$ Ibid., 104.

${ }^{34}$ Benedict S. Jimenez and Rebecca Hendrick. "Is Government Consolidation the Answer?" State and Local Government Review 42 (2010): 258-270.

${ }^{5}$ Highsmith. Demolition Means Progress, 140.
} 
opportunity hoarding common to Tieboutian thinking. ${ }^{36}$

Pursuant to the failure of New Flint, civic leaders attempted to recapture lost tax revenue by selectively attempting to annex outlying factories and sprawling business strips in the growing suburbs. In response, residents of one township incorporated as a city in 1972, and others banded together to introduce state legislation to protect "charter" townships from urban annexation. The enactment of a 1978 bill known as HB 4030 gave townships the same legal powers as central cities, so long as basic tax base and public service criteria were met. ${ }^{37}$ An attorney working for a suburban township insisted that amalgamation constituted an "injustice" for the township due to their recent infrastructure investments, although he failed to acknowledge the history of Flint providing services to said suburbs and the fact that the very existence of the suburbs was linked to the rising economic fortunes of the city. Suburbanites maintained that if Flint's leaders desired new development, they should clear built-up land in the city.

In the wake of the defeat of New Flint and subsequent annexation attempts, Flint and its people found themselves up against a wall of hostile suburbs, ${ }^{38}$ unable to expand the city's boundaries while simultaneously hemorrhaging tax base to outlying areas. As an economic strategy, during this period, Flint's mayor and city commissioners considered proposals to attract additional industry to impoverished black residential neighborhoods, a process of urban renewal that began in the early 1960s but carried more weight after the failed consolidation and annexation attempts. ${ }^{39}$ Over time, this clearance of black neighborhoods would have profound implications for population shifts, racial and economic inequality, and tax base decline.

\section{Civil rights and deindustrialization: social and economic change exacerbates fragmented governance}

Civil rights efforts for open housing had a compounding effect on antiurban feelings among whites in the suburbs. Flint enacted a municipal fair housing ordinance in $1968 .^{40}$ Shortly after that, federal legislators passed the national Fair Housing Act, which prohibited most forms of racially motivated housing discrimination. In Flint and elsewhere, however, the political and jurisdictional separation of the suburbs placed limits on such civil rights gains, as outlying suburban municipalities retained many discriminatory housing and zoning practices that excluded both poor and black residents. The

\footnotetext{
${ }^{36}$ George Lipsitz. "From Plessy to Ferguson." Cultural Critique 90 (2015): 119-139; Tilly. Durable Inequality.

${ }^{37}$ Highsmith. Demolition Means Progress, 141-144, 243-245.

${ }^{38}$ Ibid., 141-144.

${ }^{39}$ Sidney Fine. "Michigan and Housing Discrimination, 1949-1968." The Michigan Historical Review 23 (1997): 81114; Thomas C. Henthorn. "A Catholic Dilemma: White Flight in Northwest Flint." The Michigan Historical Review 31 (2005): $1-42$.

${ }^{40}$ Fine. "Michigan and Housing Discrimination"; Highsmith. Demolition Means Progress, 147-199.
}

constriction of Flint by its suburbs-along with local officials' desire to grow the tax base in a city that was increasingly losing middle-class residents to those suburbs-precipitated the city's turn toward urban renewal for new industrial and commercial land. ${ }^{41}$

The destructive and competitive nature of Tiebout's philosophy surfaced dramatically during this era. In the 1960s and early 1970s, government authorities worked to secure new investment by approving the construction of a new urban freeway and designating more than 1000 acres of predominately black residential neighborhoods for clearance. The particularly grave injustice in this process was that because of delays in approving the city's redevelopment plans, land values in renewal neighborhoods declined precipitously, leaving home and business owners ill-compensated for their properties. The effect was the displacement and dispossession of thousands of predominately black Flint residents, many of whom had been property owners. This displacement also sped up white flight to the suburbs as the black population spilled over into previously segregated white enclaves within the city. $^{42}$

Blockbusting by real estate agents and fears of racial conflict fueled the departure of thousands of white families from the city in the 1960 s and 1970 s. ${ }^{43}$ In this era of massive displacement, suburbanites sought to reestablish the color line by isolating themselves in politically separate municipalities. Meanwhile, real estate agents steered black families into racially transitional neighborhoods within Flint. Before the enactment of the Fair Housing Act, whites in Flint could buffer themselves from integration through explicitly racist means. After 1968, however, suburbanites increasingly embraced exclusionary zoning and building codes, home rule, and other ostensibly colorblind practices that in reality perpetuated exclusion along lines of both race and class. ${ }^{44}$

Once in separate municipalities, suburbanites felt functionally absolved from the legacy infrastructure and social problems they had helped to create, ${ }^{45}$ opting instead to develop duplicated infrastructures (as noted above). Howell-Moroney notes that such "boundaries serve to artificially circumscribe notions of collective responsibility." 46 This was certainly the case in the Flint area during the postwar and civil rights eras, when

\footnotetext{
${ }^{41}$ Other scholars have made this point. See, for example, Robert O. Self. American Babylon: Race and the Struggle for Postwar Oakland (Princeton University Press, 2003).

${ }^{42}$ Highsmith. Demolition Means Progress, 175-199.

${ }^{43}$ Richard Casey Sadler and Don Lafreniere. "Racist Housing Practices as a Precursor to Uneven Neighborhood Change in a Post-Industrial City." Housing Studies (2016); DOI: 10.1080/ 02673037.2016.1181724.

${ }^{44}$ Highsmith. Demolition Means Progress, 216-221; Hutson, et al. "Metropolitan Fragmentation"; Sacoby Wilson, Malo Hutson, and Mahasin Mujahid. "How Planning and Zoning Contribute to Inequitable Development, Neighborhood Health, and Environmental Injustice." Environmental Justice 1 (2008): $211-216$

${ }^{45}$ Discussed for gentrifying cities in Powell. "Race, Poverty, and Urban Sprawl," 1-20.

${ }^{46}$ Howell-Moroney. "The Tiebout Hypothesis."
} 
suburbanites resisted desegregation and increasingly severed their ties to the city. ${ }^{47}$

Deindustrialization hit Flint particularly hard during the late twentieth century. Because Flint's economy rested heavily on the production of large, energy-inefficient automobiles, the energy crises and economic recessions of the 1970s and 1980s dealt the city particularly devastating blows. As GM executives ordered layoffs and plant closures, the city went into an economic tailspin. Between 1955 and 1987, Flint lost 34,000 jobs. ${ }^{48}$ In the wake of these economic setbacks, municipalities in the metropolitan region fought over increasingly shrinking slices of an economic pie, as each sought to retain the quality of infrastructure constructed during the boom years.

\section{Contemporary disinvestment: punitive measures, antiurban bias, and fiscal crises}

Alongside joblessness and poverty, property abandonment and rising fears of crime created additional disincentives to remain in Flint. Between 1960 and 2015, the city's population dropped from nearly 200,000 to below $100,000{ }^{49}$ With its ability to grow inhibited by incorporated suburbs, and its own population and economic base shrinking, Flint's financial position increasingly worsened during the late twentieth and early twenty-first centuries. Each household and business that moved away made the situation more precarious. Due in large measure to declining revenue, Flint was thus unable to sustain its infrastructure, despite charging increasingly high rates for water and other basic services. ${ }^{50}$ Moreover, deliberate disinvestment in cities by the state government only hastened the fiscal crisis that led to state takeovers, first in 2002, and more recently in 2011.

Rather than creating a pro-business local economic development climate, the state of Michigan enacted a pair of punitive measures that exacerbated Flint's financial and infrastructural woes. Embracing a Tieboutian approach to the distribution of government funds, in 2003, the Michigan legislature sharply reduced revenue sharing with municipalities, from $\$ 900$ million to $\$ 250$ million annually. ${ }^{51}$ The revenue sharing arrangement had previously positioned central cities as the major economic drivers of regional economies. Due to this change, however, Flint lost \$54.9 million between 2003 and 2014. Reflecting on Flint's 2012 deficit of $\$ 19.2$ million,

\footnotetext{
${ }^{47}$ Highsmith. Demolition Means Progress. Much the same occurred in other metropolitan areas in the United States. See, for example, Kevin M. Kruse. White Flight: Atlanta and the Making of Modern Conservatism (Princeton University Press, 2005).

${ }^{48}$ Highsmith Demolition Means Progress, 242-267.

49" Flint, Michigan Population History." <http://www. biggestuscities.com/city/flint-michigan $>$. (Last accessed on July 18, 2016).

${ }^{50}$ Highsmith. Demolition Means Progress, 242-285; Highsmith. "Failing Flint"; John Wisely. "Flint Residents Paid America's Highest Water Rates." Detroit Free Press 17 February 2016.

${ }^{51}$ Anthony Minghine. "The Great Revenue Sharing Heist." Michigan Municipal League Review, March/April 2014.
}

one writer pointed out that with the lost revenue sharing funds, "Flint could eliminate the deficit and pay off all $\$ 30$ million of bonded indebtedness and still have over $\$ 5$ million in surplus.", 52

Exacerbating matters, a punitive new emergency manager law enacted in 2011 (PA 4) allowed state officials to take over municipal finances with the central directive to cut spending. ${ }^{53}$ Although Michigan voters overturned PA 4 in 2012, the Michigan legislature moved quickly to enact a replacement law (PA 436), which strengthened the powers of emergency managers and prohibited referenda on the issue. ${ }^{54}$ Flint was under emergency financial management throughout the 3-year period leading up to the FWC, due in considerable measure to these reductions in revenue sharing. As critics have noted, the citizens who have experienced these state takeovers since 2009 constitute just $9.7 \%$ of the state population but $49.8 \%$ of its black population. ${ }^{55}$ Given both the known negative consequences of municipal fragmentation and Michigan's practice of punishing rather than aiding struggling municipalities through the revocation of revenue sharing and the institution of emergency managers, it is not surprising that the FWC was the end result of this process.

\section{CONCLUSIONS}

The full story of the proximate causes of the FWC has been told elsewhere ${ }^{56}$; instead, we have focused here on the deeper historical causes of the catastrophe and how they relate to and reflect many of the inequities perpetuated by Tieboutian policies. As we have argued here, and as Figure 1 illustrates, many forces converged to generate the social and economic conditions that brought about Flint's infrastructure crisis. Paramount among them is the rigid segregation of the city's black population, first explicitly via federal and local housing and development policies and later implicitly by fragmented municipal governance. Researchers have routinely shown that this process of sorting into different municipalities as advocated in the Tiebout model has disproportionately harsh effects on minority

\footnotetext{
${ }^{52}$ Jonathan Oosting. "Michigan's \$6.2B 'Raid' on Revenue Sharing? See How Much Local Communities Have Lost since 2003." Lansing News, 18 March 2014.

${ }^{53}$ Monica Davey. "Michigan Residents Sue over Law on Emergency Management of Struggling Cities." The New York Times, 23 June 2011; Jamie Peck. "Austerity Urbanism: American Cities under Extreme Economy." City 16 (2012): 626-655.

${ }^{54}$ John Philo. "Local Government in Michigan: Democracy for the Fortunate Few." National Lawyers Guild Review 71 (2014): 65.

${ }^{55}$ David Fasenfest and Theodore Pride. "Emergency Management in Michigan: Race, Class and the Limits of Liberal Democracy." Critical Sociology 42 (2016): 331-334.

${ }^{56}$ Jennifer Dixon. "How Flint's Water Crisis Unfolded." Detroit Free Press, 20 January 2016; Flint Water Advisory Task Force. "Final Report"; Merit Kennedy. "Lead-Laced Water in Flint: A Step-by-Step Look at the Makings of a Crisis." $\mathrm{Na}$ tional Public Radio, 20 April 2016. <http://www.npr.org/ sections/thetwo-way/2016/04/20/465545378/lead-laced-water-inflint-a-step-by-step-look-at-the-makings-of-a-crisis $>$. (Last accessed on July 20, 2016).
} 
populations. In the Flint case, Tiebout-style sorting resulted in a deeply inequitable arrangement in which suburbanites - the overwhelming majority of whom were whiteeffectively deeded over the central city with the most legacy infrastructure to a disproportionately poor and minority population that had already suffered from decades of disinvestment and discrimination.

Compellingly, in 2016, the governor's task force itself found that "the facts of the Flint water crisis lead us to the inescapable conclusion that this is a case of environmental injustice.' As members of that task force further asserted, when it comes to determining whether an environmental injustice has occurred, intent is of little consequence ${ }^{57}$ Rather, these sorts of injustices take place when discrete communities-often those populated by poor people or racial minorities, as in the Flint case-are saddled with disproportionately high environmental burdens, regardless of intent.

Nevertheless, with regard to the Flint story, a measure of intent is clearly decipherable. As we have shown, many policies in Flint reflected a deliberate intent to fragment the metropolis and disinvest in the central city, which in turn created concentrated disadvantage for minority residents and the poor. That disadvantage manifested itself not only in high rates of urban poverty and racial segregation but also in the urban fiscal and infrastructural crises that have collided so powerfully since 2014. In short, much of the environmental injustice that has occurred as a result of the FWC was avoidable.

In 1969, a black Flint city commissioner offered the following warning to fleeing white residents: "Those of you who feel you will escape by running to suburbia, beware...blight recognizes no border lines." 58 In the decades since then, the steep costs of suburbanization and metropolitan fragmentation have become exceedingly apparent, not only in the Flint area but in the nation as a whole. As Jimenez and Hendrick concluded, "low-density and spatially expansive development patterns require large investments to extend roadways and other types of infrastructurerelated services over long distances to reach communities in the urban fringes." 59 Thus, the Flint metropolitan region faces a precarious long-term situation, as both urban and suburban obsolescence may precipitate further infrastructure or financial crises-scenarios for which fragmented municipal governments are currently ill prepared.

Given the vast scale of environmental injustice in cities such as Flint, policymakers in Michigan and elsewhere would be prudent to evaluate how their emphasis on suburban growth has exacerbated the disadvantages of lowincome and often minority populations. Municipal fragmentation has been a convenient tool for perpetuating the

\footnotetext{
${ }^{57}$ Flint Water Advisory Task Force. "Final Report."

${ }^{58}$ Highsmith. "Demolition Means Progress," 453-454.

${ }^{59}$ Jimenez and Hendrick. "Government Consolidation," 264 See also Robert W. Burchell. South Carolina Infrastructure Study: Projection of Statewide Infrastructure Costs, 1995-2015 (Center for Urban Policy Research, Rutgers University, 1997); Helen F. Ladd and John Yinger. America's Ailing Cities: Fiscal Health and the Design of Urban Policy (John Hopkins University Press, 1989).
}

illusion of separate but equal in racially heterogeneous metropolitan regions, ${ }^{60}$ but persistent social inequalities as well as the aging infrastructure of urban and, more recently, suburban municipalities will continue to pose threats to public health and well-being in the future.

While solutions exist for these problems, many remain politically unpalatable to governing elites, many of whom continue unwittingly to favor the Tiebout model. One such proposal is a hybrid form of regional governance known as federated regionalism. According to Powell, "federated regionalism is a regional approach that preserves political and cultural status within communities or cities, while sharing regional resources and responsibilities, and balanced regional policymaking." "This approach," Powell contends, "provides the opportunity to preserve and build on the assets of the inner city community while tapping into the resources and opportunities located elsewhere in the region."61 As a practical matter, this policy proposal may be difficult to achieve politically since it would ultimately entail the resurrection of some form of revenue sharing. Additional partial solutions may include stricter enforcement of fair housing laws; dense urban development with a range of housing types and costs; a renewed emphasis on school desegregation and consolidation; the prioritization of transportation, public health, and infrastructure investments in existing urban areas; policy changes to address wealth and employment imbalances between impoverished urban and suburban areas and more affluent suburban job centers; and community economic development programs to encourage more equitable and socially advantageous forms of urban redevelopment. ${ }^{62}$

If policymakers in Michigan and elsewhere are serious about addressing social and environmental injustices and improving the economic competitiveness of central cities, they must act decisively and in ways that deviate from Michigan's (and the nation's) antiurban past. In the absence of such a major shift, residents of metropolitan

\footnotetext{
${ }^{60}$ DeHoog, Lowery, and Lyons. "Metropolitan Fragmentation"; Freund. Colored Property; N.E. Long. "Political Science and the City." In: Leo F. Schnore and Henry Fagin, eds., Urban Research and Policy Planning (Sage Publications, 1967), 243262.

${ }^{61}$ Powell. "Race, Poverty, and Urban Sprawl," 8.

${ }^{62}$ Julian Agyeman and Tom Evans. "Toward Just Sustainability in Urban Communities: Building Equity Rights with Sustainable Solutions." The Annals of the American Academy of Political and Social Science 590 (2003): 35-53; Elizabeth Burton. "Housing for an Urban Renaissance: Implications for Social Equity." Housing Studies 18 (2003): 537-562; Peter Calthorpe and William Fulton. The Regional City (Island Press, 2001); Peter Dreier, John H. Mollenkopf, and Todd Swanstrom. Place Matters: Metropolitics for the Twenty-First Century (University Press of Kansas, 2004); Howell-Moroney. "The Tiebout Hypothesis"; Daniel J. Hutch. "The Rationale for Including Disadvantaged Communities in the Smart Growth Metropolitan Development Framework." Yale Law \& Policy Review 20 (2002): 353-368; Russell P. Lopez and H. Patricia Hynes. "Obesity, Physical Activity, and the Urban Environment: Public Health Research Needs." Environmental Health 5 (2006): 1; Orfield. American Metropolitics; Orfield. Must We Bus?; Edward W. Soja. "Regional Urbanization and the End of the Metropolis Era." In: Gary Bridge and Sophie Watson, eds., The New Blackwell Companion to the City (Wiley-Blackwell, 2011), 679-689.
} 
regions such as Flint will, at best, face the rising costs of service provision for declining and inadequate infrastructure and, at worst, endure additional, and perhaps even more catastrophic, public health crises.

APPROXIMATE PERIODIZATION OF MAJOR EVENTS PRECIPITATING THE FWC

Industrial Growth (1910s-1945)

Post-World War II Development (1945-1960)

New Flint and Regionalism (1958-1970s)

Civil Rights and Deindustrialization (1968-1980s)

Contemporary Disinvestment (1990s-Present).
AUTHOR DISCLOSURE STATEMENT

No competing financial interests exist.

Address correspondence to: Richard Casey Sadler Division of Public Health

Michigan State University 200 East 1st Street Room 337

Flint, MI 48502

E-mail: sadlerr@msu.edu 


\section{This article has been cited by:}

1. Alison Singer, Steven Gray, Artina Sadler, Laura Schmitt Olabisi, Kyle Metta, Renee Wallace, Maria Claudia Lopez, Josh Introne, Maddie Gorman, Jane Henderson. 2017. Translating community narratives into semi-quantitative models to understand the dynamics of socio-environmental crises. Environmental Modelling \& Software 97, 46-55. [Crossref]

2. Richard C. Sadler, Don J. Lafreniere. 2017. You are where you live: Methodological challenges to measuring children's exposure to hazards. Journal of Children and Poverty 23:2, 189-198. [Crossref]

3. Michael B. Rosen, Lok R. Pokhrel, Mark H. Weir. 2017. A discussion about public health, lead and Legionella pneumophila in drinking water supplies in the United States. Science of The Total Environment 590-591, 843-852. [Crossref]

4. Richard Casey Sadler, Jesenia Pizarro, Brandon Turchan, Stephen P. Gasteyer, Edmund F. McGarrell. 2017. Exploring the spatialtemporal relationships between a community greening program and neighborhood rates of crime. Applied Geography 83, 13-26. [Crossref]

5. Richard Casey Sadler, Jenny LaChance, Mona Hanna-Attisha. 2017. Social and Built Environmental Correlates of Predicted Blood Lead Levels in the Flint Water Crisis. American Journal of Public Health 107:5, 763-769. [Crossref] 